\title{
Performance of Sulfuric Acid Leaching of Titanium from Titanium-Bearing Electric Furnace Slag
}

\author{
XiaoMing $\mathrm{Qu}^{1}$, YuFeng Guo ${ }^{1}$, FuQiang Zheng ${ }^{1}$, Tao Jiang ${ }^{1} \&$ GuanZhou Qiu ${ }^{1}$ \\ ${ }^{1}$ School of Minerals Processing and Bioengineering, Central South University, Changsha 410083, Hunan, China. \\ Correspondence: YuFeng Guo, School of Minerals Processing and Bioengineering, Central South University, \\ Changsha 410083, Hunan, China. E-mail: guoyufengcsu@163.com \\ FuQiang Zheng, School of Minerals Processing and Bioengineering, Central South University, Changsha 410083, \\ Hunan, China. E-mail: zhengfuqiangcsu@163.com
}

Received: June 11, 2016

Accepted: July 27, 2016

Online Published: August 6, 2016

doi:10.5539/jmsr.v5n4p1

URL: http://dx.doi.org/10.5539/jmsr.v5n4p1

\begin{abstract}
The sulfuric acid leaching of titanium from titanium-bearing electric furnace slag (TEFS) was investigated under different experimental conditions. In the sulfuric acid leaching process, the $\mathrm{M}_{\mathrm{x}} \mathrm{Ti}_{3-\mathrm{x}} \mathrm{O}_{5}(0 \leqslant \mathrm{x} \leqslant 2)$ and diopside could react with sulfuric acid. The optimum conditions of sulfuric acid leaching process were particle size at $<$ $0.045 \mathrm{~mm}$, sulfuric acid concentration at $90 \mathrm{wt} . \%$, acid/slag mass ratio at $1.6: 1$, feeding temperature at $120{ }^{\circ} \mathrm{C}$, reaction temperature at $220{ }^{\circ} \mathrm{C}$, reaction time at 120 minute, curing at $200^{\circ} \mathrm{C}$ for 120 minute. The $\left[\mathrm{TiO}_{2}\right]$ concentration of the water leaching was $150 \mathrm{~g} / \mathrm{L}$, and leaching temperature at $60^{\circ} \mathrm{C}$ for 120 minute. Ti extraction could reach $84.29 \%$. F of titanium-bearing solution was 2.15 , and the $\mathrm{Ti}^{3+} / \mathrm{TiO}_{2}$ of the titanium-bearing solution was 0.068 . The $\mathrm{TiO}_{2}$ content of the leaching residue was $18.32 \mathrm{wt} . \%$. The main mineral phases of the leaching residue were calcium sulphate, spinel, diopside and little $\mathrm{M}_{\mathrm{x}} \mathrm{Ti}_{3-\mathrm{x}} \mathrm{O}_{5}$.
\end{abstract}

Keywords: Sulfuric acid leaching, Titanium-bearing electric furnace slag, Ti extraction

\section{Introduction}

Vanadium titanomagnetite ore is an important resource of iron, vanadium and titanium. The Panzhihua-Xichang region of China is rich in vanadium titanomagnetite resources with reserves of about 9.66 billion tons which contained $11.6 \%$ of vanadium and $35.17 \%$ of titanium all over the world (Zheng et al., 2016; U.S. Geological Survey, 2015). At present, the vanadium titanomagnetite ore is separated as ilmenite concentrate, vanadium titanomagnetite concentrate and other minerals in Panzhihua-Xichang region. The vanadium titanomagnetite concentrate containing about $52 \%$ titanium and $89 \%$ vanadium of the vanadium titanomagnetite ore is used to produce iron and extract vanadium by the conventional blast furnace process. However, the titanium remains in the titanium-bearing blast furnace slag $\left(22-25 \mathrm{wt} \% \mathrm{TiO}_{2}\right)$ without effective utilization. The sodium salt roasting-direct reduction-electric furnace smelting, direct reduction-magnetic separation and some other methods has been studied to utilize the titanium resource in the vanadium titanomagnetite concentrate, but these methods have been in the stage of laboratory research (Peng \& Hwang, 2015; Samanta, Mukherjee, \& Dey, 2015; Chen et al., 2015; Taylor \& Shuey, 2006). The direct reduction-electric furnace smelting process has been commercialized in South Africa and New Zealand (Jen, Dresler, \& Reilly, 1995) due to large production scale and mature recovery method of vanadium in molten iron. The direct reduction-electric furnace smelting process is also more environmentally friendly than blast furnace process. The titanium-bearing electric furnace slag (TEFS) of the direct reduction-electric smelting process contains $40-60 \mathrm{wt} . \% \mathrm{TiO}_{2}$ which is much higher than the $\mathrm{TiO}_{2}$ content of titanium-bearing blast furnace slag. Therefore, it is crucial to effectively extract titanium from TEFS for the development of direct reduction-electric furnace smelting and the utilization of the vanadium titanomagnetite concentrate.

Currently, few effort has been made to recover titanium from TEFS (Li et al., 2013; Zheng et al., 2016). Other studies focused on recover titanium from titanium-bearing blast furnace slag. Ma et al. (2000) separated titanium from treated slag by gravity separating or flotation. Hydrometallurgical methods include leaching of titanium slag with sulfuric acid (Farzaneh et al., 2013) or hydrochloric acid (Wang et al., 1994). Wang et al. (2012) recovered titanium from titanium-bearing blast furnace slag by ammonium sulfate melting method. Photocatalytic materials (Lü et al., 2013) and Ti-Si ferroalloy (Li et al., 1996) were prepared using blast furnace titaniferous slag. Wang et 
al. (2006) separated titanium components from titanium bearing blast furnace slag by the selective separation technique. Liu (2009) recovered titanium by high-temperature carbonization and low-temperature chlorination from modified titanium bearing blast furnace slag. Although some of processes have been proved to extract titanium from titanium slag, the application of these processes may result in high cost, poor recovery and environmental pollution problem. Among these methods, apart from the sulfuric acid leaching process which is a mature titanium dioxide process, other methods are all in the stage of laboratory research. Recovery of titanium by sulfuric acid can not only treat titanium slag in large-scale, but also promote the process of direct reduction-electric furnace smelting by utilizing the titanium resource in the vanadium titanomagnetite concentrate. Therefore, studying the performance of sulfuric acid leaching of titanium from TEFS is very necessary.

The performance of sulfuric acid leaching affected by a variety of parameters. In the present study, a list of conditions of sulfuric acid leaching of TEFS was investigated, with an emphasis on the effects of particle sizes, liquid/solid ratio, sulfuric acid concentration, feeding temperature, reaction temperature, Curing time, cooling rate, $\mathrm{TiO} 2$ concentration of water leaching, water leaching temperature time. The findings will provide a technical basis for titanium dioxide preparation by sulfuric acid leaching process of TEFS.

\section{Experimental}

\subsection{Materials}

The TEFS used in the present work was provided by Chongqing Steel (Sichuan Province, China). The chemical analysis of the sample is listed in Table 1. It can be seen that the $\mathrm{TiO}_{2}$ content of the TEFS is $47.35 \mathrm{wt} . \%$, and the major impurities are aluminum, silicon, magnesium, and calcium-bearing diopside and spinel. The mineral composition of the sample was investigated by X-ray diffractometer (D/max2550PC, Japan Rigaku Co., Ltd). The XRD pattern of the slag is showed in Figure 1. The major phases in the TEFS are $\mathrm{M}_{\mathrm{x}} \mathrm{Ti}_{3-\mathrm{x}} \mathrm{O}_{5}(0 \leqslant \mathrm{x} \leqslant 2)$, diopside and spinel. All reagents used in the experiments were of at least analytical grade provided by Hunan Chashang Chemical Reagents Factory.

Table 1. Chemical composition of the original titanium slag

\begin{tabular}{cccccccc}
\hline Component & $\mathrm{TiO}_{2}$ & $\mathrm{TFe}$ & $\mathrm{V}_{2} \mathrm{O}_{5}$ & $\mathrm{Al}_{2} \mathrm{O}_{3}$ & $\mathrm{SiO}_{2}$ & $\mathrm{MgO}$ & $\mathrm{CaO}$ \\
\hline wt. $\%$ & 47.35 & 3.16 & 0.49 & 12.10 & 16.08 & 9.88 & 9.97 \\
\hline
\end{tabular}

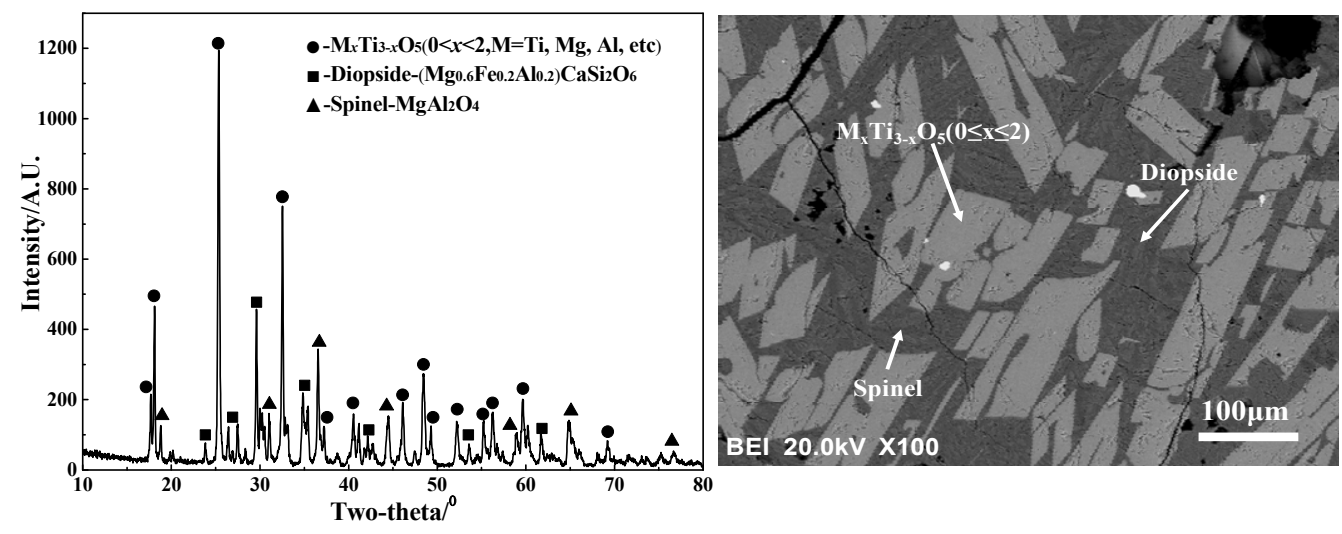

Figure 1. XRD pattern and micrograph of the original TEFS

\subsection{Experimental Procedure}

TEFS was crushed to a certain size and screened by tyler sieve. A certain amount of concentrated sulfuric acid were heated to the feed temperature in a beaker by an oil bath pan, then a certain quality of sample was added into the sulfuric acid followed by stirring at $20 \mathrm{rpm}$. Then the temperature of the leaching system was attempered to a certain reaction temperature in 2 minute. After the reaction finishing, the beaker was transferred to the muffle furnace at curing temperature for a certain time. Then the curing material was cooled to room temperature, and a certain quality of water was added to dissolve the curing material at a certain temperature for a required time. At last, the leaching solution was filtered to obtain the titanium-bearing solution and leaching residue. The leaching 
residue was dried in an oven at $105{ }^{\circ} \mathrm{C}$ for $4 \mathrm{~h}$. The property of titanium-bearing solution and leaching residue were analyzed by EDTA titration.

The Ti extraction is defined as follows:

$$
\eta_{\mathrm{Ti}}=\left[1-\left(\frac{m \times \omega_{\mathrm{Ti}}}{m_{0} \times \omega_{0}}\right)\right]
$$

Where $\eta_{\mathrm{Ti}}$ is the Ti extraction, $\mathrm{m}$ is the quality of the leaching residue (g, dried solids), $w_{\mathrm{Ti}}$ is the content of Ti in the leaching residue (wt.\%, dried solids), $m_{0}$ is the initial mass of slag sample (g, dried solids), $w_{0}$ is the content of Ti in the slag sample (wt. $\%$, dried solids).

\subsection{Experiment Principle}

The main mineral of titanium slag is $\mathrm{MxTi} 3-\mathrm{xO} 5(0 \leq \mathrm{x} \leq 2)$, which reacts with sulfuric acid can be simply expressed as:

$$
\begin{aligned}
& \mathrm{Mg} \mathrm{Ti}_{2} \mathrm{O}_{5}(\mathrm{~s})+6 \mathrm{H}^{+}(\mathrm{aq})=\mathrm{Mg}^{2+}(\mathrm{aq})+2 \mathrm{TiO}^{2+}(\mathrm{aq})+3 \mathrm{H}_{2} \mathrm{O} \\
& \mathrm{FeTi}_{2} \mathrm{O}_{5}(\mathrm{~s})+6 \mathrm{H}^{+}(\mathrm{aq})=\mathrm{Fe}^{2+}(\mathrm{aq})+2 \mathrm{TiO}^{2+}(\mathrm{aq})+3 \mathrm{H}_{2} \mathrm{O}
\end{aligned}
$$

The main gangues in the slag are spinel and diopside. The main reactions could occur in the solution can be simply expressed as:

$$
\begin{gathered}
\mathrm{MgAl}_{2} \mathrm{O}_{4}(\mathrm{~s})+8 \mathrm{H}^{+}(\mathrm{aq})=\mathrm{Mg}^{2+}(\mathrm{aq})+3 \mathrm{Al}^{3+}(\mathrm{aq})+4 \mathrm{H}_{2} \mathrm{O} \\
\mathrm{CaSiO}_{3}(\mathrm{~s})+2 \mathrm{H}^{+}(\mathrm{aq})=\mathrm{Ca}^{2+}(\mathrm{aq})+\mathrm{H}_{2} \mathrm{SiO}_{3}(\mathrm{~s}) \\
\mathrm{MgSiO}_{3}(\mathrm{~s})+2 \mathrm{H}^{+}(\mathrm{aq})=\mathrm{Mg}^{2+}(\mathrm{aq})+\mathrm{H}_{2} \mathrm{SiO}_{3}(\mathrm{~s}) \\
\mathrm{FeSiO}_{3}(\mathrm{~s})+2 \mathrm{H}^{+}(\mathrm{aq})=\mathrm{Fe}^{2+}(\mathrm{aq})+\mathrm{H}_{2} \mathrm{SiO}_{3}(\mathrm{~s}) \\
\mathrm{Al}_{2} \mathrm{SiO}_{5}(\mathrm{~s})+6 \mathrm{H}^{+}(\mathrm{aq})=2 \mathrm{Al}^{3+}(\mathrm{aq})+\mathrm{H}_{2} \mathrm{SiO}_{3}(\mathrm{~s})+2 \mathrm{H}_{2} \mathrm{O}
\end{gathered}
$$

\section{Results and discussion}

\subsection{Effect of the Particle Size on Sulfuric Acid Leaching}

Several leaching experiments were performed in $90 \mathrm{wt} . \% \mathrm{H}_{2} \mathrm{SO}_{4}$ solution with different particle sizes, acid/slag mass ratio at $1.6: 1$, feeding temperature at $100^{\circ} \mathrm{C}$, reaction temperature at $200^{\circ} \mathrm{C}$, curing temperature at $200{ }^{\circ} \mathrm{C}$, curing time for 120 minute, and the water leaching conditions were leaching $\left[\mathrm{TiO}_{2}\right]$ concentration at $150 \mathrm{~g} / \mathrm{L}$, water leaching temperature at $60^{\circ} \mathrm{C}$, water leaching time for 120 minute. The results are listed in Table 2.

Table 2. Effect of the particle size on sulfuric acid leaching

\begin{tabular}{llll}
\hline Particle size $/ \mathrm{mm}$ & $\mathrm{Ti}$ extraction $/ \%$ & $\mathrm{Ti}^{3+} / \mathrm{TiO}_{2}$ & $\mathrm{~F}$ \\
\hline$>0.074$ & 80.11 & 0.075 & 2.46 \\
$0.045-0.074$ & 80.76 & 0.076 & 2.44 \\
$<0.045$ & 81.93 & 0.077 & 2.40 \\
\hline
\end{tabular}

The results in Table 2 show that the Ti extraction and $\mathrm{Ti}^{3+} / \mathrm{TiO}_{2}$ in the leaching solution are increased with decreasing of slag particle size. $\mathrm{F}$ decreases with decreasing of particle size. More slag was decomposed by $\mathrm{H}_{2} \mathrm{SO}_{4}$, less effective acid was remained in the leaching solution which lead to the decreasing of $F$. 


\subsection{Effect of the Acid/Solid Ratio on Sulfuric Acid Leaching}

The effect of liquid/solid ratio was investigated in $90 \mathrm{wt} . \% \mathrm{H}_{2} \mathrm{SO}_{4}$ solution with different particle sizes $<0.045 \mathrm{~mm}$, feeding temperature at $100{ }^{\circ} \mathrm{C}$, reaction temperature at $200{ }^{\circ} \mathrm{C}$, curing temperature at $200{ }^{\circ} \mathrm{C}$, curing time for 120 minute, and the water leaching conditions were leaching $\left[\mathrm{TiO}_{2}\right]$ concentration at $150 \mathrm{~g} / \mathrm{L}$, water leaching temperature at $60{ }^{\circ} \mathrm{C}$, water leaching time for 120 minute. T Results are presented in Figure 2.

Ti extraction and $\mathrm{F}$ increased with the increasing of acid/slag ratio, because more sulfuric acid could improve the acidolysis of TEFS, at the same time, more effective acid were remained in the leaching solution. When the acid/slag ratio increased from 1.6 to 1.7 , the F increased sharply from 2.4 to 2.8 . Higher F would be a big obstacle for $\mathrm{Ti}^{4+}$ hydrolyzing. Thus the optimum acid/slag ratio was selected as 1.6:1 and applied in the subsequent experiments.

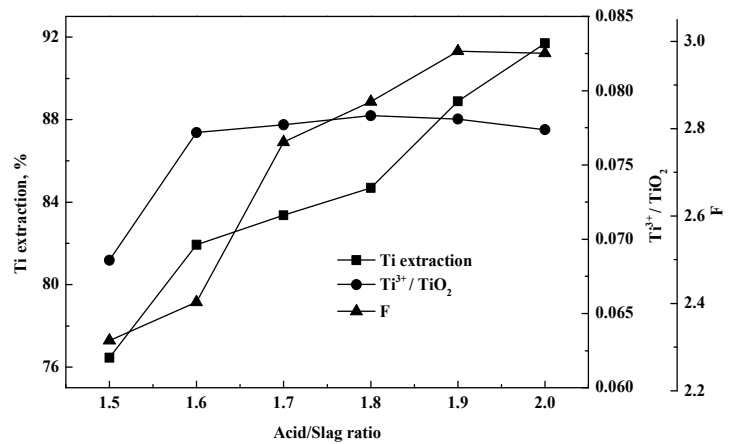

Figure 2. Effect of the Liquid/Solid ratio on sulfuric acid leaching

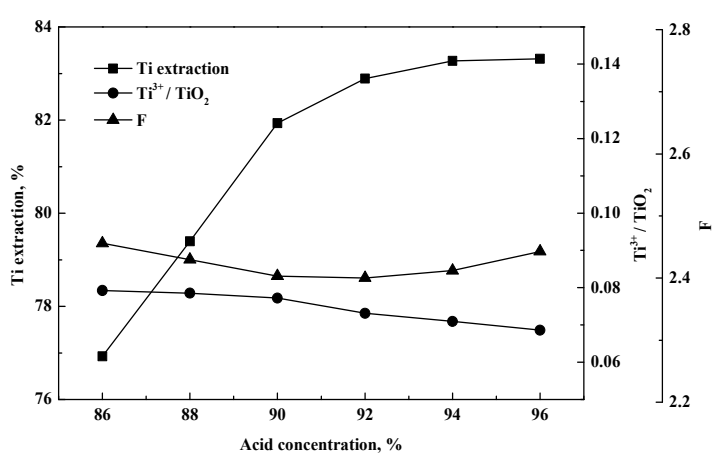

Figure 3. Effect of the Acid concentration ratio on sulfuric acid leaching

\subsection{Effect of the sulfuric Acid Concentration on Sulfuric Acid Leaching}

Figure 3 shows the results of experiments which carried out with acid/slag mass ratio at 1.6:1, feeding temperature at $100{ }^{\circ} \mathrm{C}$, reaction temperature at $200^{\circ} \mathrm{C}$, curing temperature at $200^{\circ} \mathrm{C}$, curing time for 120 minute, and the water leaching conditions were leaching $\left[\mathrm{TiO}_{2}\right]$ concentration at $150 \mathrm{~g} / \mathrm{L}$, water leaching temperature at $60{ }^{\circ} \mathrm{C}$, water leaching time for $120 \mathrm{~min}$ and the $\mathrm{H}_{2} \mathrm{SO}_{4}$ concentration varied from $86 \%$ to $96 \%$ with particle size $<0.045 \mathrm{~mm}$.

The results in Figure 3 showed that increasing $\mathrm{H}_{2} \mathrm{SO}_{4}$ concentration had an effectively effect on the Ti extraction. When the $\mathrm{H}_{2} \mathrm{SO}_{4}$ concentration was at $86 \mathrm{wt} . \%$, the Ti extraction was $76.9 \%$. However, $83.3 \%$ of Ti extraction was obtain when the $\mathrm{H}_{2} \mathrm{SO}_{4}$ concentration was at $94 \mathrm{wt} . \%$. On the other hand, the $\mathrm{Ti}^{3+} / \mathrm{TiO}_{2}$ decreased with the increasing of $\mathrm{H}_{2} \mathrm{SO}_{4}$ concentration. The $\mathrm{F}$ was slightly increased when the $\mathrm{H}_{2} \mathrm{SO}_{4}$ concentration was higher than 92 wt.\%. The optimum sulfuric acid concentration was $94 \%$.

\subsection{Effect of the Feeding Temperature on Sulfuric Acid Leaching}

A series of experiments was carried out in $90 \mathrm{wt} . \% \mathrm{H}_{2} \mathrm{SO}_{4}$ solution with varied feeding temperature from $25^{\circ} \mathrm{C}$ to $140^{\circ} \mathrm{C}$, and the other conditions was particle size $<0.045 \mathrm{~mm}$, acid/slag mass ratio of at $1.6: 1$, reaction temperature at $200{ }^{\circ} \mathrm{C}$, curing temperature at $200{ }^{\circ} \mathrm{C}$, curing time for 120 minute. And the water leaching conditions were leaching $\left[\mathrm{TiO}_{2}\right]$ concentration at $150 \mathrm{~g} / \mathrm{L}$, water leaching temperature at $60^{\circ} \mathrm{C}$, water leaching time for 120 minute.

The results in Figure 4 showed that with the increasing of feeding temperature from $20^{\circ} \mathrm{C}$ to $120^{\circ} \mathrm{C}$, Ti extraction increased to $83.64 \%, \mathrm{Ti}^{3+} / \mathrm{TiO}_{2}$ dropped to $0.068, \mathrm{~F}$ dropped to 2.40 . While the feed temperature raised to $140^{\circ} \mathrm{C}$, $\mathrm{Ti}$ extraction dropped quickly, $\mathrm{Ti}^{3+} / \mathrm{TiO}_{2}$ and $\mathrm{F}$ reached the peak values. The optimum Feed temperature was $120^{\circ} \mathrm{C}$.

\subsection{Effect of the Reaction Temperature on Sulfuric Acid Leaching}

The effect of Reaction temperature was investigated in 94 wt. $\% \mathrm{H}_{2} \mathrm{SO}_{4}$ solution with particle size $<0.045 \mathrm{~mm}$, acid/slag mass ratio of at $1.6: 1$, curing at $200^{\circ} \mathrm{C}$ for $120 \mathrm{~min}$ and the water leaching conditions were leaching $\left[\mathrm{TiO}_{2}\right]$ concentration at $150 \mathrm{~g} / \mathrm{L}$, water leaching at $60{ }^{\circ} \mathrm{C}$ for 120 minute. Reaction temperature varied from $160{ }^{\circ} \mathrm{C}$ to $250{ }^{\circ} \mathrm{C}$. Results are presented in Figure 5.

The results in Figure 5 showed that increasing reaction temperature has effectively effects on the Ti extraction. When the reaction temperature increased to $220^{\circ} \mathrm{C}$, the $\mathrm{Ti}$ extraction raised to $84.29 \%$, the $\mathrm{Ti}^{3+} / \mathrm{TiO}_{2}$ dropped to 
0.067. When the reaction temperature reached $250^{\circ} \mathrm{C}$, the Ti extraction dropped and the $\mathrm{Ti}^{3+} / \mathrm{TiO}_{2}$ raised. The $\mathrm{F}$ decreased with the increasing of reaction temperature. The optimum reaction temperature was $220^{\circ} \mathrm{C}$.

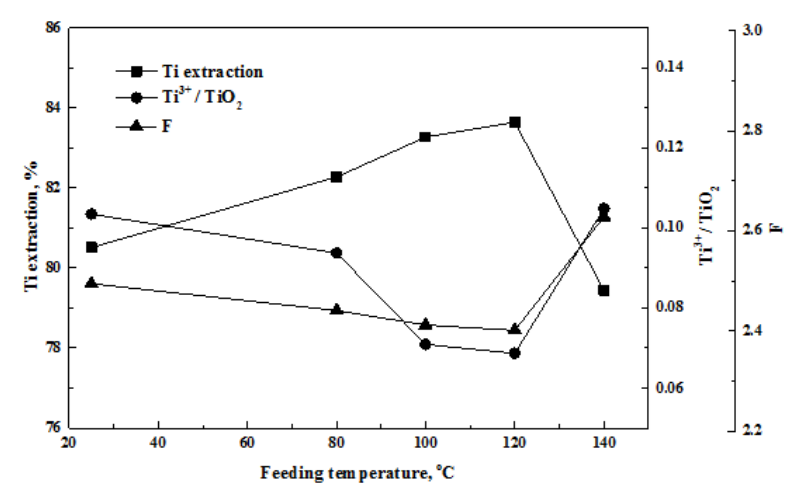

Figure 4. Effect of the feed temperature on sulfuric acid leaching

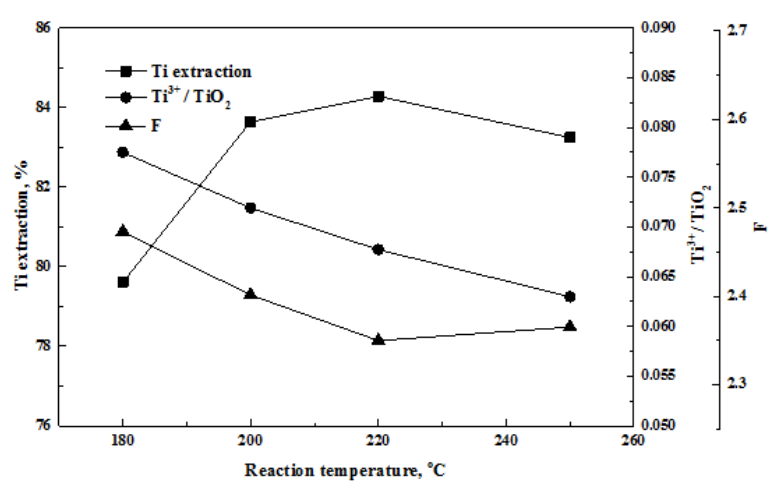

Figure 5. Effect of the reaction temperature on sulfuric acid leaching

\subsection{Effect of the Curing Time on Sulfuric Acid Leaching}

The effect of curing time was investigated in $90 \mathrm{wt} . \% \mathrm{H}_{2} \mathrm{SO}_{4}$ solution with particle size $<0.045 \mathrm{~mm}$, acid/slag mass ratio of at $1.6: 1$, feeding temperature at $100{ }^{\circ} \mathrm{C}$, reaction temperature at $200{ }^{\circ} \mathrm{C}$, curing temperature at $200{ }^{\circ} \mathrm{C}$, curing time varied from 0 to 180 minute, and the water leaching conditions were leaching $\left[\mathrm{TiO}_{2}\right]$ concentration at $150 \mathrm{~g} / \mathrm{L}$, water leaching temperature at $60^{\circ} \mathrm{C}$, water leaching time for 120 minute.

The Figure 6 showed that with the increased of the curing time, the Ti extraction increased, the $\mathrm{Ti}^{3+} / \mathrm{TiO}_{2}$ and $\mathrm{F}$ decreased. Before the time of $120 \mathrm{~min}$, the Ti extraction, $\mathrm{Ti}^{3+} / \mathrm{TiO}_{2}$ and $\mathrm{F}$ varied quickly. After 120 minute, the Ti extraction increased and the $\mathrm{Ti}^{3+} / \mathrm{TiO}_{2}$ varied not obviously. The optimum curing time was 120 minute.

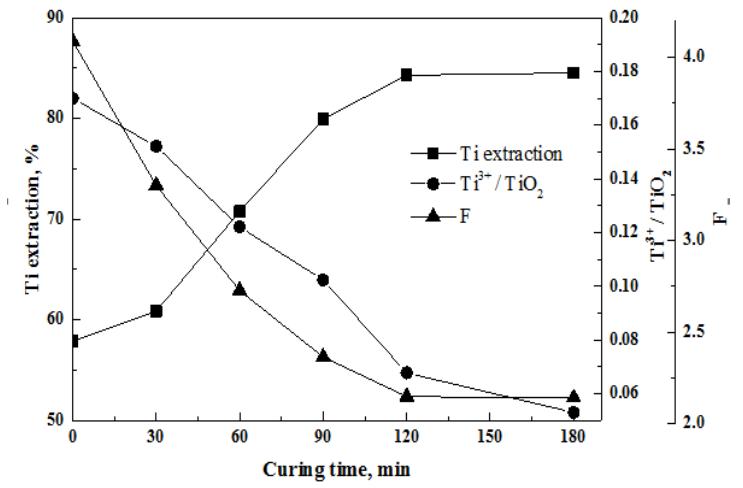

Figure 6. Effect of the curing time on sulfuric acid leaching

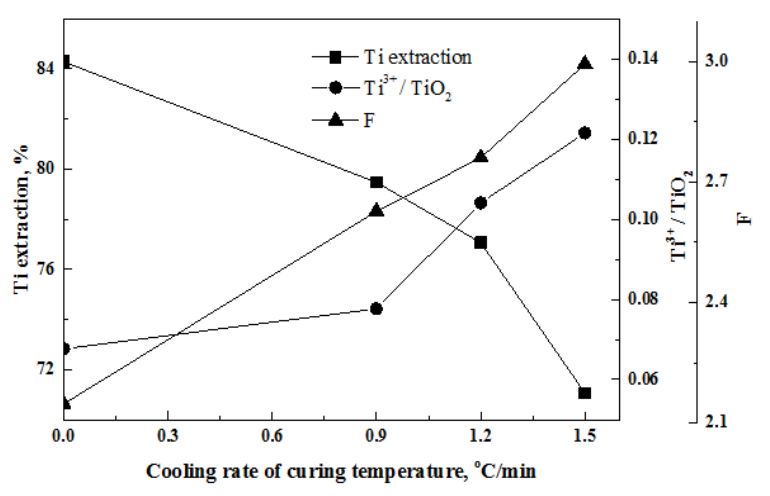

Figure 7. Effect of the cooling rate of curing temperature on sulfuric acid leaching

\subsection{Effect of the Cooling Rate of Curing Temperature on Sulfuric Acid Leaching}

For the present experiments, the initial curing temperature were $200^{\circ} \mathrm{C}$ with the cooling rate ranged from 0 to $1.5{ }^{\circ} \mathrm{C} /$ minute. Particle size $<0.045 \mathrm{~mm}$ in $90 \mathrm{wt} . \% \mathrm{H}_{2} \mathrm{SO}_{4}$ solution, acid/slag mass ratio of at $1.6: 1$, feeding temperature at $100{ }^{\circ} \mathrm{C}$, reaction temperature at $200{ }^{\circ} \mathrm{C}$, and the water leaching conditions were leaching $\left[\mathrm{TiO}_{2}\right]$ concentration at $150 \mathrm{~g} / \mathrm{L}$, water leaching temperature at $60^{\circ} \mathrm{C}$, water leaching time for 120 minute. Figure 7 shows the influences of cooling rate of curing temperature on sulfuric acid leaching. With the increasing of cooling rate, the Ti extraction decreased, the $\mathrm{Ti}^{3+} / \mathrm{TiO}_{2}$ and $\mathrm{F}$ increased. To ensuring and increasing leaching performance, the cooling rate should keep as low as possible. 


\subsection{Effect of the Leaching Concentration on Water Leaching}

The effect of leaching concentration on water leaching was investigated in $90 \mathrm{wt} . \% \mathrm{H}_{2} \mathrm{SO}_{4}$ solution with particle size $<0.045 \mathrm{~mm}$, acid/slag mass ratio of at $1.6: 1$, feeding temperature at $100{ }^{\circ} \mathrm{C}$, reaction temperature at $200{ }^{\circ} \mathrm{C}$, curing temperature at $200{ }^{\circ} \mathrm{C}$, curing time for 120 minute, but the water leaching conditions of leaching $\left[\mathrm{TiO}_{2}\right]$ concentration varied from $120 \mathrm{~g} / \mathrm{L}$ to $150 \mathrm{~g} / \mathrm{L}$, water leaching temperature at $60{ }^{\circ} \mathrm{C}$, water leaching time for 120 minute.

The results in Figure 5 showed that leaching $\left[\mathrm{TiO}_{2}\right]$ concentration had obvious improvement on $\mathrm{Ti}^{3+} / \mathrm{TiO}_{2}$ and $\mathrm{F}$. The leaching $\left[\mathrm{TiO}_{2}\right]$ concentration from $150 \mathrm{~g} / \mathrm{L}$ to $170 \mathrm{~g} / \mathrm{L}$, the Ti extraction decreased and the $\mathrm{Ti}^{3+} / \mathrm{TiO}_{2}$ increased sharply. High leaching concentration was good for the concentration process. High leaching $\left[\mathrm{TiO}_{2}\right]$ concentration also made the solid phase products dissolved and the Ti extraction decreased.

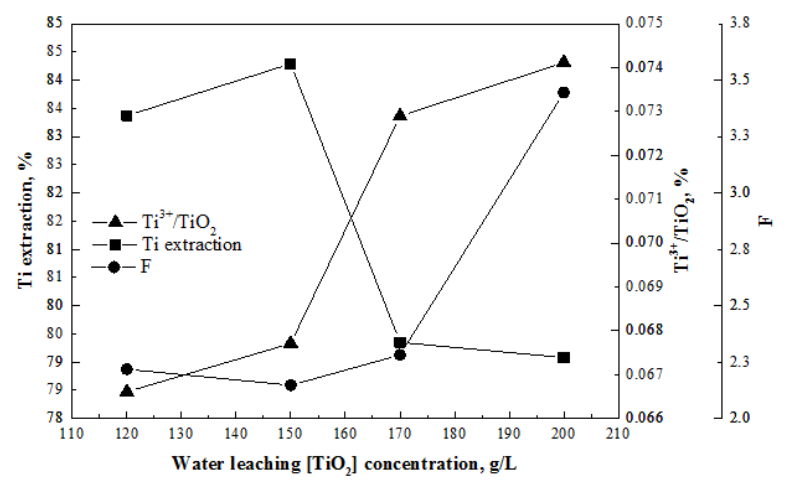

Figure 8. Effect of the leaching $\left[\mathrm{TiO}_{2}\right]$ concentration on water leaching

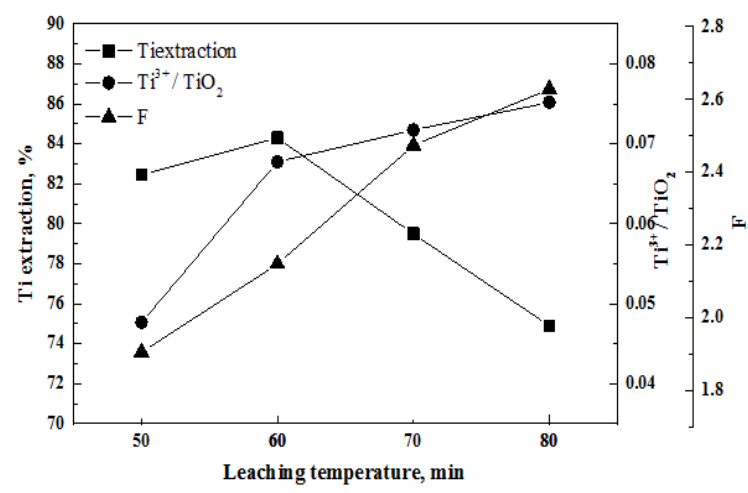

Figure 9. Effect of the leaching temperature on water leaching

\subsection{Effect of the Leaching Temperature on Water Leaching}

The effect of leaching temperature on water leaching was investigated in $90 \mathrm{wt} . \% \mathrm{H}_{2} \mathrm{SO}_{4}$ solution with particle size $<0.045 \mathrm{~mm}$, acid/slag mass ratio of at $1.6: 1$, feeding temperature at $100^{\circ} \mathrm{C}$, reaction temperature at $200{ }^{\circ} \mathrm{C}$, curing temperature at $200{ }^{\circ} \mathrm{C}$, curing time for $120 \mathrm{~min}$ and the water leaching conditions were leaching $\left[\mathrm{TiO}_{2}\right]$ concentration at $150 \mathrm{~g} / \mathrm{L}$, water leaching temperature ranged from $50^{\circ} \mathrm{C}$ to $80{ }^{\circ} \mathrm{C}$, water leaching time for 120 minute.

The results in Figure 9 showed that $\mathrm{Ti}^{3+} / \mathrm{TiO}_{2}$ and $\mathrm{F}$ were increased with the increasing of water leaching temperature. When the water leaching temperature was above $60{ }^{\circ} \mathrm{C}$, Ti extraction decreased sharply. In the leaching process, most of the salt dissolved in water releasing quantity of heatwhich leaded to the temperature increased. Excessively high water leaching temperatures leaded to titanium hydrolysis ahead of time. The optimum leaching temperature was $60^{\circ} \mathrm{C}$.

\subsection{Effect of the Leaching Time on Water Leaching}

The effect of leaching time on water leaching was investigated in 90 wt. $\% \mathrm{H}_{2} \mathrm{SO}_{4}$ solution with particle size $<0.045 \mathrm{~mm}$, acid/slag mass ratio of at $1.6: 1$, feeding temperature at $100^{\circ} \mathrm{C}$, reaction temperature at $200^{\circ} \mathrm{C}$, curing temperature at $200^{\circ} \mathrm{C}$, curing time for 120 minute and the water leaching conditions were leaching $\left[\mathrm{TiO}_{2}\right]$ concentration at $150 \mathrm{~g} / \mathrm{L}$, water leaching temperature at $60^{\circ} \mathrm{C}$, water leaching time for 60 minute, 120 minute, 180 minute respectively.

The results in Figure 10 showed that $\mathrm{Ti}^{3+} / \mathrm{TiO}_{2}$ and $\mathrm{Ti}$ extraction were increased with the rise in temperature, the $\mathrm{F}$ decreased with the rise in temperature. The optimum leaching temperature is 2 hours. 


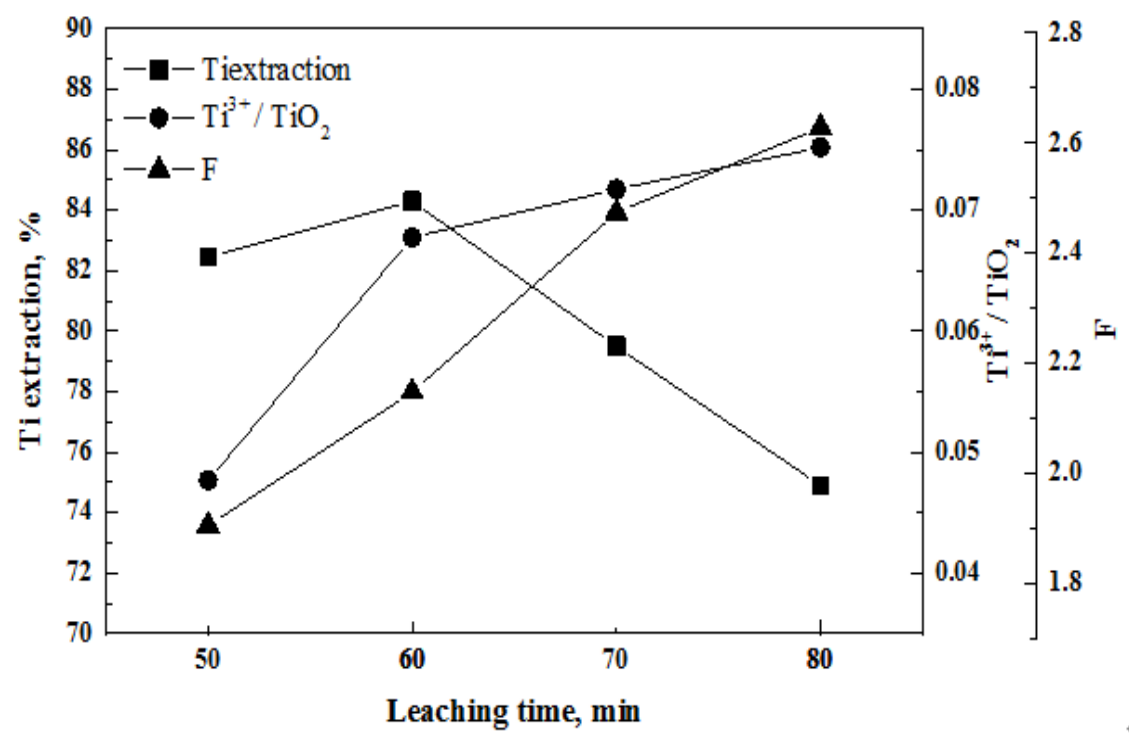

Figure 10. Effect of the leaching time on water leaching

\section{11 The Titanium Solution and Leaching Residue}

The optimum conditions of sulfuric acid leaching were particle size at $<0.045 \mathrm{~mm}$, sulfuric acid concentration at $90 \mathrm{wt} . \%$, acid/slag mass ratio at $1.6: 1$, feeding temperature at $120^{\circ} \mathrm{C}$, reaction temperature at $220^{\circ} \mathrm{C}$, reaction time of 120 minute, curing temperature at $200^{\circ} \mathrm{C}$ for 120 minute. The water leaching $\left[\mathrm{TiO}_{2}\right]$ concentration were $180 \mathrm{~g} / \mathrm{L}$, leaching temperature at $60^{\circ} \mathrm{C}$ for 120 minute. Ti extraction could reach $84.29 \%$, F of lixivium was $2.15, \mathrm{Ti}^{3+} / \mathrm{TiO}_{2}$ was $0.068, \mathrm{Ti}^{3+}$ contend was higher than the required quantity, further processing was required to reduce the $\mathrm{Ti}^{3+}$ contend. The chemical analysis of the residue and titanium solution are listed in Table 3 and Table 4 respectively. The XRD pattern of the leaching residue is showed in Figure 11.

The main mineral phases of the leaching residue were calcium sulphate, spinel, diopside and little $\mathrm{M}_{\mathrm{x}} \mathrm{Ti}_{3-\mathrm{x}} \mathrm{O}_{5} .18 .32$ wt. $\% \mathrm{TiO}_{2}$ were remained in the leaching residue. The reasons were as followed. First, sulfuric acid reacted with calcium-bearing silicate and formed $\mathrm{CaSO}_{4}$ which was not soluble. $\mathrm{CaSO}_{4}$ covered on the slag particles and hindered the reaction. Second, $\mathrm{M}_{\mathrm{x}} \mathrm{Ti}_{3-\mathrm{x}} \mathrm{O}_{5}$ were so stable that it could not be completely dissolved by sulfuric acid.

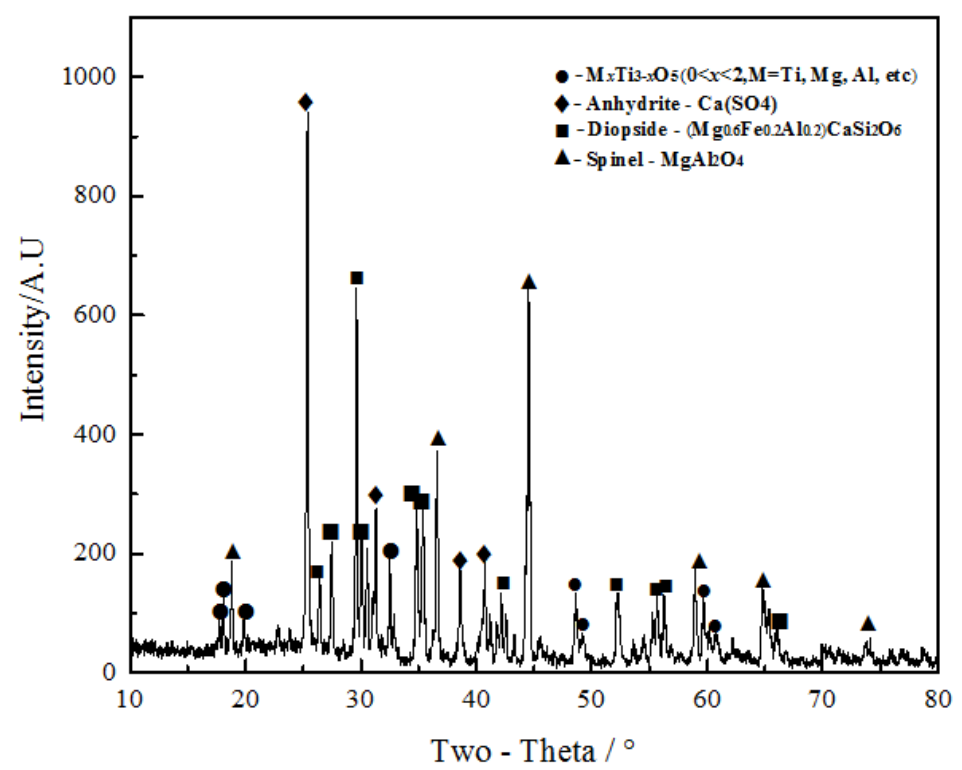

Figure 11. XRD pattern of the sulfuric leaching residue 
Table 3. Chemical composition of the leaching residue

\begin{tabular}{lllllll}
\hline Component & $\mathrm{TiO}_{2}$ & $\mathrm{MgO}$ & $\mathrm{Fe}_{2} \mathrm{O}_{3}$ & $\mathrm{Al}_{2} \mathrm{O}_{3}$ & $\mathrm{SiO}_{2}$ & $\mathrm{CaO}$ \\
\hline wt.\% & 18.321 & 12.448 & 2.252 & 14.601 & 26.579 & 13.333 \\
\hline
\end{tabular}

Table 4. Chemical composition of titanium solution

\begin{tabular}{lllllll}
\hline Component & $\mathrm{TiO}_{2}$ & $\mathrm{MgO}$ & $\mathrm{Fe}_{2} \mathrm{O}_{3}$ & $\mathrm{Al}_{2} \mathrm{O}_{3}$ & $\mathrm{SiO}_{2}$ & $\mathrm{CaO}$ \\
\hline Extraction $\%$ & $84.44 \%$ & $52.86 \%$ & $43.06 \%$ & $58.04 \%$ & $5.38 \%$ & $2.22 \%$ \\
Content $\mathrm{g} / \mathrm{L}$ & 156.210 & 21.938 & 2.676 & 31.734 & 2.376 & 0.477 \\
\hline
\end{tabular}

\section{Conclusion}

The major phases in the TEFS are $\mathrm{M}_{\mathrm{x}} \mathrm{Ti}_{3-\mathrm{x}} \mathrm{O}_{5}(0 \leqslant \mathrm{x} \leqslant 2)$, diopside and spinel. In the sulfuric acid leaching process, the $\mathrm{M}_{\mathrm{x}} \mathrm{Ti}_{3-\mathrm{x}} \mathrm{O}_{5}(0 \leqslant \mathrm{x} \leqslant 2)$ and diopside could react with sulfuric acid. The optimum condition of sulfuric acid leaching were particle size at $<0.045 \mathrm{~mm}, 90 \mathrm{wt} \%$ sulfuric acid concentration, acid/slag mass ratio at 1.6:1, feeding temperature at $120{ }^{\circ} \mathrm{C}$, reaction temperature at $220{ }^{\circ} \mathrm{C}$, reaction time at 120 minute, curing at $200{ }^{\circ} \mathrm{C}$ for 120 minute. The water leaching $\left[\mathrm{TiO}_{2}\right]$ concentration were $150 \mathrm{~g} / \mathrm{L}$, water leaching at $60^{\circ} \mathrm{C}$ for 120 minute. Ti extraction could reach $84.29 \%$, F of lixivium was $2.15, \mathrm{Ti}^{3+} / \mathrm{TiO}_{2}$ was 0.068 . The main mineral phases of the leaching residue were calcium sulphate, spinel, diopside and little $\mathrm{M}_{\mathrm{x}} \mathrm{Ti}_{3-\mathrm{x}} \mathrm{O}_{5}$ During the leaching process, CaSO4 were generated and covered on the surface of slag particles.

\section{Acknowledgments}

The authors are grateful to the Program for New Century Excellent Talents in University from Chi-nese Ministry of Education (NCET-10-0834) and the Visiting Scholar Program from China Scholarship Council ([2013]3018) for supporting this research.

\section{References}

Chen, D., Zhao, H., Hu, G., Qi, T., Yu, H., Zhang, G., ... \& Wang, W. (2015). An extraction process to recover vanadium from low-grade vanadium-bearing titanomagnetite. Journal of hazardous materials, 294, 35-40. https://doi.org/10.1016/j.jhazmat.2015.03.054

Jena, B. C., Dresler, W., \& Reilly, I. G. (1995). Extraction of titanium, vanadium and iron from titanomagnetite deposits at pipestone lake, Manitoba, Canada. Minerals engineering, 8(1), 159-168. https://doi.org/10.1016 /0892-6875(94)00110-X

Li, Y., Yue, Y., Que, Z. Q., Zhang, M., \& Guo, M. (2013). Preparation and visible-light photocatalytic property of nanostructured fe-doped tio2 from titanium containing electric furnace molten slag. International Journal of Minerals Metallurgy and Materials, 20(10), 1012-1020. https://doi.org/10.1007/s12613-013-0828-y

Li, Z., Xu, C., Li, Z., \& Zhou, Y. (1996). The study on smelting ti-si ferroalloy by dc electrothermal process using pisc blast furnace titaniferous slag. Journal of Chongqing University.

Liu, X. H. (2009). Study on High-temperature Carbonization and Low-temperature Chlorination on Modified Titanium Bearing Blast Furnace Slag. Northeastern University, Shenyang (in Chinese).

Lü, H., Li, N., Wu, X., Li, L., Gao, Z., \& Shen, X. (2013). A novel conversion of ti-bearing blast-furnace slag into water splitting photocatalyst with visible-light-response. Metallurgical and Materials Transactions B, 44(6), 1317-1320.

Ma, J., Sui, Z., \& Chen, B. (2000). Separating titanium from treated slag by gravity separation/flotation. Nonferrous Metals-Beijing-, 52(2), 26-31.

Peng, Z., \& Hwang, J. Y. (2015). Microwave-assisted metallurgy. International Materials Reviews, 60(1), 30-63. https://doi.org/10.1179/1743280414Y.0000000042

Samanta, S., Mukherjee, S., \& Dey, R. (2015). Upgrading metals via direct reduction from poly-metallic titaniferous magnetite ore. JOM, 67(2), 467-476. https://doi.org/10.1007/s11837-014-1203-9

Taylor, P. R., Shuey, S. A., Vidal, E. E., \& Gomez, J. C. (2006). Extactive metallurgy of vanadium-containing titaniferous magnetite ores: A review. Minerals and Metallurgical Processing, 23(2), 80-86.

U.S. Geological Survey. (2015). Mineral commodity summaries 2015. Center for Integrated Data Analytics Wisconsin Science Center. https://doi.org/10.3133/70140094 
Valighazvini, F., Rashchi, F., \& Nekouei, R. K. (2013). Recovery of titanium from blast furnace slag. Industrial and Engineering Chemistry Research, 52(4), 1723-1730. https://doi.org/10.1021/ie301837m

Wang, D. K., Lei, M. L., Li, B. E., \& Jiang, Z. Q. (1994). A process for comprehensive utilization of blast furnace slag with dilute hydrochloric acid. Chinese Patent CN94108086.2.

Wang, M. Y., Zhang, L. N., Zhang, L., Sui, Z. T., \& Tu, G. F. (2006). Selective enrichment of tio2 and precipitation behavior of perovskite phase in titania bearing slag.Transactions of Nonferrous Metals Society of China, 16(2), 421-425. https://doi.org/10.1016/S1003-6326(06)60072-1

Wang, S., Zhang, Y., Xue, X., \& Yang, H. (2012). Recovery of titanium from titanium-bearing blast furnace slag by ammonium sulfate melting method. Ciesc Journal, 63(3), 991-995. https://doi.org/10.3969/j.issn. 0438-1157.2012.03.045

Zheng, F., Chen, F., Guo, Y., Jiang, T., Travyanov, A. Y., \& Qiu, G. (2016). Kinetics of hydrochloric acid leaching of titanium from titanium-bearing electric furnace slag. Jom the Journal of the Minerals Metals and Materials Society, 30(30), 15-68. https://doi.org/10.1007/s11837-015-1808-7

\section{Copyrights}

Copyright for this article is retained by the author(s), with first publication rights granted to the journal.

This is an open-access article distributed under the terms and conditions of the Creative Commons Attribution license (http://creativecommons.org/licenses/by/4.0/). 